FIU Law Review

\title{
The Prospects and Challenges of Educational Reform for Latino Undocumented Children: An Essay Examining Alabama's H.B. 56 and Other State Immigration Measures
}

\author{
María Pabón López \\ Loyola University New Orleans College of Law \\ Diomedes J. Tsitouras \\ Indiana University School of Law, Indianapolis \\ Pierce C. Azuma
}

Follow this and additional works at: https://ecollections.law.fiu.edu/lawreview

Part of the Other Law Commons

Online ISSN: 2643-7759

Recommended Citation

María P. López, Diomedes J. Tsitouras \& Pierce C. Azuma, The Prospects and Challenges of Educational Reform for Latino Undocumented Children: An Essay Examining Alabama's H.B. 56 and Other State Immigration Measures, 6 FIU L. Rev. 231 (2011).

DOI: https://dx.doi.org/10.25148/lawrev.6.2.6

This Article is brought to you for free and open access by eCollections. It has been accepted for inclusion in FIU Law Review by an authorized editor of eCollections. For more information, please contact lisdavis@fiu.edu. 


\title{
The Prospects and Challenges of Educational Reform for Latino Undocumented Children: An Essay Examining Alabama's H.B. 56 and Other State Immigration Measures
}

\author{
María Pabón López, Diomedes J. Tsitouras, \& Pierce C. Azuma*
}

\section{INTRODUCTION: UNDOCUMENTED STUDENTS IN THE UNITED STATES AND ALABAMA's H.B. 56}

In May 2010, First Lady Michelle Obama was visiting a suburban Washington, D.C. elementary school when a second grader said to her, "[m]y mom ... says that Barack Obama is taking everybody away that doesn't have papers." Mrs. Obama responded, "that's something that we have to work on, right? ... To make sure that people can be here with the right kind of papers, right? That's exactly right." ${ }^{2}$ The young girl then disclosed, "[b]ut my mom doesn't have any papers." " If this second grade girl had been in Alabama, after the enactment of Alabama's House Bill 56 ("H.B. 56"), the school officials would have been

\footnotetext{
María Pabón López, Dean and Judge Adrian G. Duplantier Distinguished Professor of Law, Loyola University New Orleans College of Law, A.B. Princeton University, J.D. University of Pennsylvania School of Law; Diomedes J. Tsitouras, B.S. Cornell University, M.P.A., Cornell University, J.D., Indiana University School of Law, Indianapolis; Pierce C. Azuma, B.A., Tulane University, J.D. Loyola University New Orleans College of Law. Dean López appreciates the kind invitation of Professor Ediberto Román to present an earlier version of this paper at the panel on "The Possibilities for Immigration Reform" at the "Latinos and Latinas at the Epicenter of American Legal Discourse" ("LLEADS") \#2 Conference, Florida International University School of Law, Miami, Florida, on February 24, 2011. The authors are grateful to Brian C. Barnes, Deputy Library Director of the Law Library at Loyola University New Orleans College of Law, who provided outstanding research support for this essay. The authors thank Kenneth "Doug" Walker, Editor in Chief, Carlos Rodriguez-Cabarrocas, Managing Editor, and the rest of the Florida International University Law Review, for their excellent editorial work, for their consummate professionalism, and their extraordinary generosity in the preparation of this essay.

1 Stephanie Condon, Second Grader to Michelle Obama: "My Mom Doesn't have any Papers,” CBS NEws (May 19, 2010), http://www.cbsnews.com/8301-503544_162-20005436503544.html (also recounted in Amici Curiae Brief for the National Education Association, the Alabama Education Association, and the National Education Association Supporting PlaintiffsAppellants, infra note 55, at 31).

2 Id.

$3 \quad I d$.
} 
obligated to report the child's mother's violation of H.B. 56 or risk jail time.

Despite the fact that the United States Supreme Court decided Plyler v. Doe in 1982, a case which guarantees undocumented students access to a free public K-12 education, Latino undocumented students continue to experience daunting challenges to attend school. An example of such an obstacle is the recent enactment of Alabama's H.B. 56. ${ }^{6}$ Enacted in June of 2011 as an immigration restriction measure, H.B. 56 has several provisions that directly and adversely impact the ability of undocumented children to attend school.

This essay analyzes the provisions of H.B. 56 that affect the education of undocumented children and examines the constitutionality of the provisions in view of current federal law, as embodied in the Plyler case. As immigration law is an area of federal legislative authority, a key constitutional concern is whether the Alabama law is preempted. Following the analysis of whether this law is preempted, this essay further discusses the recent litigation filed following the passage of this act. We also examine other recently-enacted state antiimmigrant measures that pose obstacles to undocumented students and conclude by offering thoughts regarding the use of children as pawns in the raging immigration debate in the United States.

\section{OVERVIEW OF CURRENT FEDERAL LAW AND H.B. 56}

\section{A. Plylerv. Doe}

The landmark case Plyler $v$. Doe established the legal norm that states may not restrict public education based on immigration status. In Plyler, a Texas statute withheld funding for the education of undocumented students and permitted school districts to ban undocumented students from enrolling if they did not pay for their schooling. ${ }^{10}$ At issue was whether the Texas statute violated the Equal Protection Clause of the Fourteenth Amendment. ${ }^{11}$ The Court held in the

4 Plyler v. Doe, 457 U.S. 202 (1982). For a recent in-depth and excellent scholarly analysis of this case, see Michael A. Olivas, No Undocumented Child Left Behind: PLYLER $V$. DoE AND THE EDUCATION OF UNDOCUMENTED SCHOOL CHILDREN (2012).

5 See Plyler, 457 U.S. 202.

62011 Ala. Laws 535 (H.B. $56 \S 2$ ).

7 United States v. Alabama, 831 F. Supp. 2d 1282, 1292 (N.D. Ala. 2011); 2011 ALA. LAWS 535 (H.B. 56 §).

8 Beason-Hammon Ala. Taxpayer and Citizen Protection Act, 2011 AlA. LAWs 535 (H.B. $56 \S 2)$.

$9 \quad$ Plyler, 457 U.S. 202.

$10 \quad$ Id. at 202.

11 Id. 
affirmative, ${ }^{12}$ using an elevated form of rational basis review. ${ }^{13}$ The Court stated that "[i]t is difficult to understand precisely what the State hopes to achieve by promoting the creation and perpetuation of a subclass of illiterates within our boundaries, surely adding to problems and costs of unemployment, welfare, and crime., ${ }^{14}$

In Plyler, for the first time, the Supreme Court clearly stated that undocumented persons are protected under the Equal Protection Clause of the Fourteenth Amendment. ${ }^{15}$ Thus, the undocumented plaintiff children used the Equal Protection Clause to challenge the state of Texas's denial of free public K-12 education. ${ }^{16}$ The Court performed an Equal Protection analysis, starting with the recognition that education is "perhaps the most important function of state and local governments." The Court found that the state's denial of an education to undocumented students could hardly be considered rational unless it furthered some substantial state goal. ${ }^{18}$ In assessing the rationality of the Texas statute, the Court warned that the cost to the nation and to the innocent children involved must be taken into account. ${ }^{19}$ The Court also found that "it is doubtful that any child may reasonably be expected to succeed in life if he is denied the opportunity of an education, ${ }^{, 20}$ and that because the state took it upon itself to provide an education to children, it had to be made "available to all on equal terms.. ${ }^{21}$

Expressing concern that it would be unfair to penalize undocumented students for their parents' unlawful presence in the United States, the Court found that undocumented children "can affect neither their parents' conduct nor their own status." ${ }^{23}$ The Court concluded that there could be no rational justification for penalizing the children for their presence in the country because the Texas law was

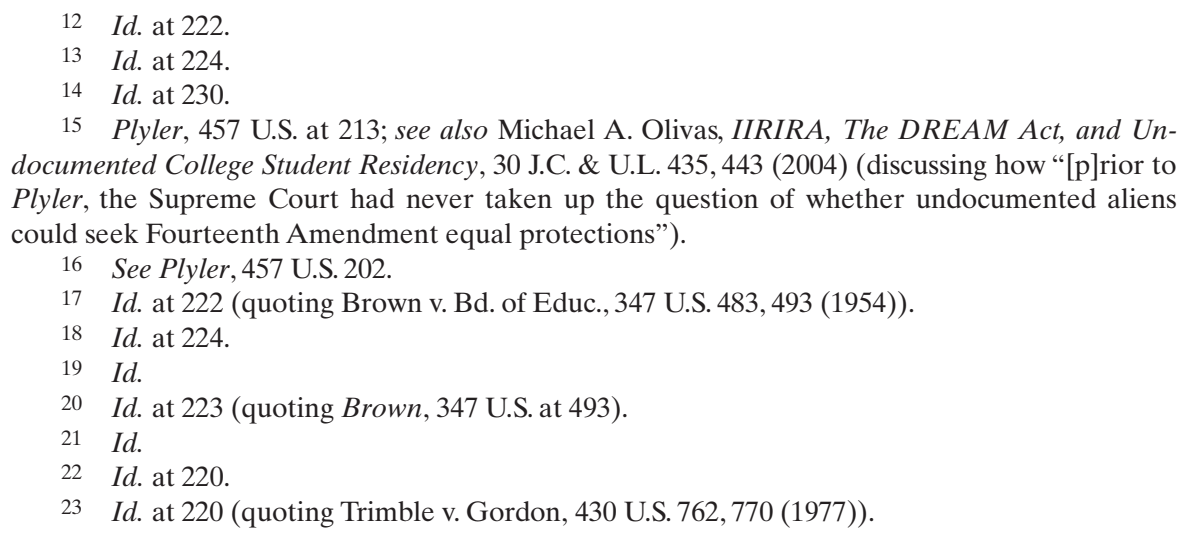
documented College Student Residency, 30 J.C. \& U.L. 435, 443 (2004) (discussing how “[p]rior to Plyler, the Supreme Court had never taken up the question of whether undocumented aliens could seek Fourteenth Amendment equal protections").

16 See Plyler, 457 U.S. 202.

17 Id. at 222 (quoting Brown v. Bd. of Educ., 347 U.S. 483, 493 (1954)).

18 Id. at 224.

20 Id. at 223 (quoting Brown, 347 U.S. at 493).

1 Id.

2 Id. at 220.

3 Id. at 220 (quoting Trimble v. Gordon, 430 U.S. 762, 770 (1977)).

$19 \quad I d$. 
directed towards children and imposed its discriminatory burden on the basis of a characteristic over which the children had no control. ${ }^{2}$

\section{B. Examination of H.B. 56 and its Provisions that Implicate Plyler}

H.B. 56 has several sections that pose a threat to an undocumented student's Plyler-based access to a K-12 education: specifically, Sections $5,8,13$, and $28{ }^{25}$ Section 28 is particularly concerning since it contains extensive information-gathering requirements that may hinder school enrollment for undocumented children. ${ }^{26}$ Section $28(\mathrm{a})(1)$ mandates that school officials inquire as to whether the enrolled child "was born outside the jurisdiction of the United States." Section 28(a)(2) asks parents to provide a valid birth certificate for the child. ${ }^{28}$ If the parent cannot produce one, he or she may produce a document establishing citizenship or immigration status, or a sworn declaration that the child is a "citizen or an alien lawfully present in the United States." ${ }^{29}$ If neither of these can be presented, the child is deemed to be "an alien unlawfully present in the United States.",

Administrators use the information from these questions to prepare an annual document to the Alabama Department of Education. This document reports the number of undocumented students enrolled in the district. ${ }^{32}$ The Alabama Department of Education then uses the data to prepare an annual report to the state legislature on the costs associated with the school attendance of these undocumented students. ${ }^{33}$ The law expressly permits state and local officials to share this information with the federal government. ${ }^{34}$ Section 28 is of particular concern because of the chilling effect that it may have on the enrollment of undocumented children whose parents may fear deportation.

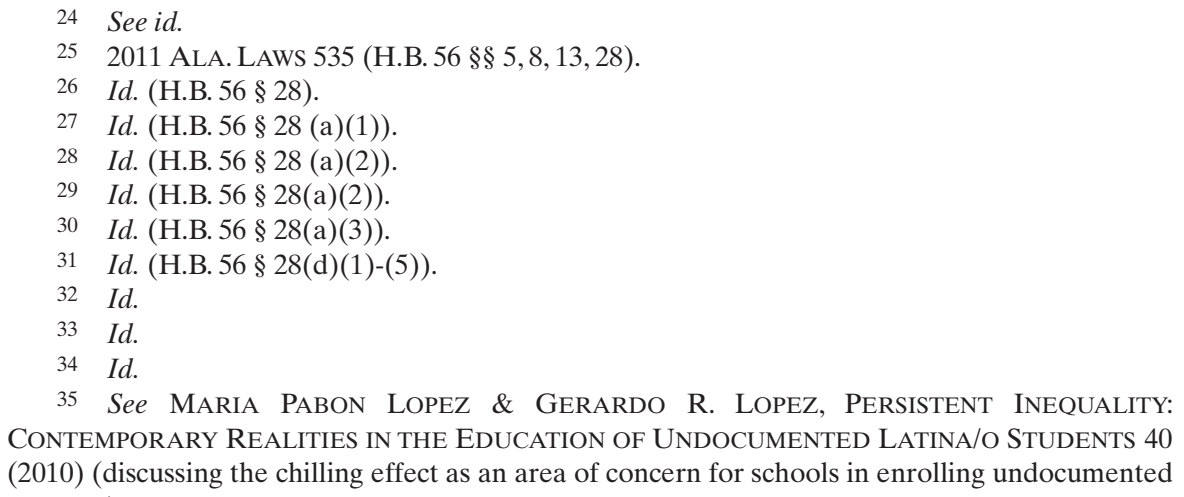
students). 
Other provisions, such as Sections 5, 8, and 13 of H.B. 56, also pose challenges regarding the education of undocumented students. ${ }^{36}$ For example, Section 5(f) requires employees of the state (including those at schools) to "report any violations of the Act.", Hence, any inadvertent disclosure of an illegal immigrant being employed in violation of Sections 11 and 15 of the Act would have to be reported. This could be done innocently, for example, by a young child, who may speak of his or her undocumented parents being at work, much in the same manner as the young girl in the Michelle Obama story discussed above. ${ }^{39}$

Section 13 of the Alabama law raises additional concerns. ${ }^{40}$ For instance, Section 13(a)(1) makes it a crime to "[c]onceal, harbor, or shield ... an alien from detection in any place in [Alabama], including any building or means of transportation, if the person knows ... the alien has come to, has entered, or remains in the United States in violation of federal law." ${ }^{, 1}$ Section 13(a)(2) makes it a criminal offense to encourage someone known to be an undocumented alien to "reside in [Alabama]." ${ }^{42}$ Furthermore, Section 13(a)(3) prohibits the knowing "transportation of undocumented alien in furtherance of the unlawful present of the alien in the United States." ${ }^{, 43}$ The provisions in Section 13 interfere with the Plyler mandate in at least two ways. First, these provisions may criminalize the actions of teachers, school administrators, and bus drivers who interact daily with undocumented students and their parents. Even if these provisions are not construed to criminalize the actions of teachers, school administrators, and bus drivers who interact daily with undocumented students and their parents, their existence may still cause the chilling effect discussed above.

Finally, Section 8 of H.B. 56 bans undocumented aliens from attending public colleges in Alabama. ${ }^{45}$ Other states such as Virginia and North Carolina have preceded Alabama in such a ban. ${ }^{46}$ Although the only federal district court opinion on point suggests that this sec-

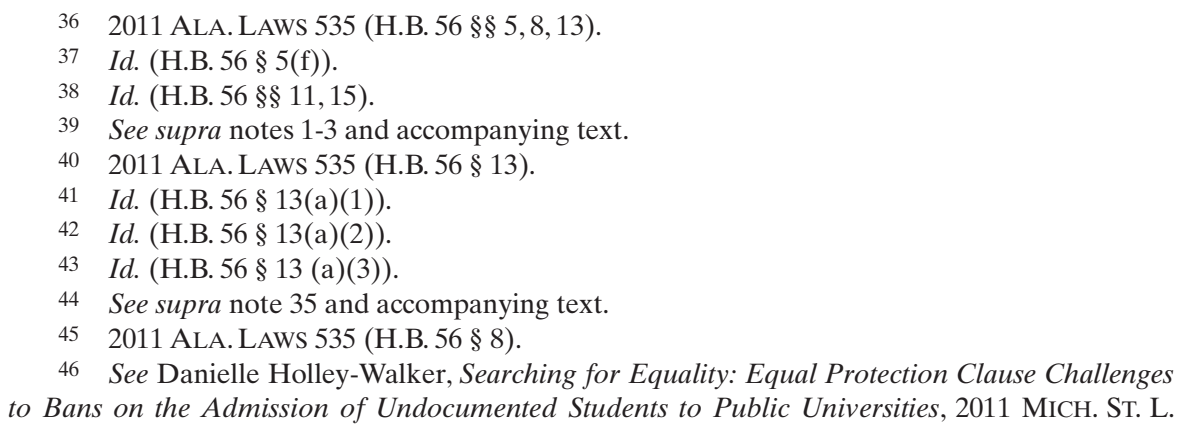


tion would pass constitutional muster, ${ }^{47}$ the section does not comport with Plyler's promise of educational equality for undocumented students. $^{48}$ While Plyler is distinguishable from Section 8 because it pertains to a K-12 education, rather than Section 8's focus on higher education, in cases following Plyler, the Supreme Court has "emphasized the importance of states providing college and graduate education."

\section{H.B. 56 Section 28 Likely Violates Plyler v. Doe}

Section 28, which requires the data collection as discussed above, contravenes Plyler. ${ }^{51}$ Alabama's undocumented students have to contend with an indirect barrier to school enrollment in the form of an information collection or registration scheme. ${ }^{52}$ This scheme acts to chill the guaranteed free public education Plyler offers.

What makes Plyler unique are the strong public policy considerations $^{53}$ in favor of the education of the undocumented children. As a result of Plyler, it has been a common practice to advise school districts against rules that would create a "chilling effect," particularly, rules that would leave undocumented parents afraid of sending their children to school for fear of being reported to the authorities. Ten states have specific guidance that instructs schools not to collect information on immigration status. ${ }^{55}$ Pennsylvania has a state statute that prevents school districts from inquiring about students' immigration status. ${ }^{56}$ Prior to the enactment of H.B. 56, the Alabama Education Department advised its school districts not to inquire into the citizenship status of children enrolling in public schools. ${ }^{57}$ Further, the

47 Equal Access Educ. v. Merten, 305 F. Supp. 2d 585 (E.D. Va. 2004). Notably, the court decision did not address the Equal Protection clause. See Holley-Walker, supra note 46, at 361.

48 See Plyler v. Doe, 457 U.S. 202 (1982).

See Holley-Walker, supra note 46, at 363.

See supra notes 25-34 and accompanying text.

2011 ALA. LAWs 535 (H.B. 56 § 28).

Id.

See Plyler, 457 U.S. 202.

See supra note 35 and accompanying text.

55 Brief for the National Education Association, the Alabama Education Association, and the National School Boards Association as Amici Curiae Supporting Plaintiffs-Appellants and Urging Reversal of the District Court's Denial of a Preliminary Injunction, at 12-14, Hispanic Interest Coal. of Ala. v. Bentley, No. 11-14535-CC (11th Cir. Oct. 14, 2011) (providing list and cites of states).

56 Id. at 14; see also 22 PA. CODE $§ 11.11(\mathrm{~d})$ (2011).

57 Alabama Department of Education, Legal Cases Related to English Language Learners, ENGLISH LANGUAGE LEARNERS, http://alex.state.al.us/ell/node/58 (last visited Mar. 10, 2012) (discussing that the Plyler "court ruled that public schools may not ... [e]ngage in any practice to 'chill' the right of access to school[, r]require students or parents to disclose or document their immigration status[, or m]ake inquiries of students or parents that may expose their undocumented status"). 
Federal Department of Education has circulated a "Dear Colleague" letter, advising states and localities on the consequences of possibly violating Plyler by "[taking] action to discourage the participation of students that could be viewed or would likely result in denying access" to public schools.

In addition to guidance from the states and the federal government, LULAC v. Wilson, the only case addressing the issue since Ply$e r$, is also persuasive. ${ }^{59}$ In LULAC, a California district court invalidated a state statute that required schools to ask about applicants' immigration status and required denial of admission to students found to be undocumented. ${ }^{60}$

Plyler, however, is not only contravened by statutes, such as the one in $L U L A C$ that bar academic admissions for undocumented students. ${ }^{61} \quad$ For instance, while H.B. 56 only requires Alabama schools to gather information for a statewide report, and it does not require schools to deny admission, the statute is still problematic from the perspective of undocumented students' access to education. ${ }^{62}$ Sure, the argument can be made that H.B. 56's information-gathering requirements are benign and can assist the state. For example, at least one scholar has stated the state of Texas in Plyler "failed to offer any credible supporting evidence that the proportionally small diminution of funds on each child ... will have a grave impact on the quality of education.," The Plyler Court also stated "the record in no way supports ... that exclusion of undocumented children is likely to improve the overall quality of education in the state. ${ }^{\prime 64}$ Scholars who support H.B. 56 assert that Alabama, unlike the State of Texas in Plyler, is only seeking to gather immigration status information so that it could offer the "credible supporting evidence" which the Plyler Court found lacking. ${ }^{65}$ Then,

[i]f the data shows that providing free education to those who are unlawfully present ... has no significant impact on education or its costs ... the Alabama law will ... not alter the status quo that

58 Plaintiffs' Motion for Preliminary Injunction and Memorandum in Support, Hispanic Interest Coal. of Ala. v. Bentley, No. 11-2484, 2011 WL 2654277 (N.D. Ala. July 8, 2011), available at http:/www.2.ed.gov/about/offices/list/ocr/letters/colleague-201101.pdf.

59 LULAC v. Wilson, 908 F. Supp. 755, 774 (C.D. Cal. 1995).

$60 \quad I d$.

61 See id.

62 See 2011 Ala. Laws 535 (H.B. 56).

63 John Eastman, Editorial, Permissible and Sensible, N.Y. TIMES (Nov. 14, 2011), http://www.nytimes.com/roomfordebate/2011/10/04/should-alabama-schools-help-catch-illegalimmigrants/alabamas-immigration-law-is-permissible-and-sensible.

64 Id.

65 Id. 
has existed since Plyler. But if the data shows that providing a free public education to illegal immigrants severely undermines the quality, and/or drastically increases the cost, of education for those who are lawful residents and citizens, the state will have met an important caveat in the Plyler decision itself. ${ }^{66}$

Scholars who support the Alabama statute and use this "credible supporting evidence" rationale, misquote and misinterpret Plyler. The correct quote from Plyler reads: "[t]here is no evidence in the record suggesting that illegal entrants impose any significant burden on the State's economy." "To the contrary, the available evidence suggests that illegal aliens underutilize public services, while contributing their labor to the economy and tax money to the state fisc." ${ }^{69}$ Further, the Plyler Court was concerned about creating a "permanent subclass of illiterates" that would lead to an increase in "unemployment, welfare, and crime." ${ }^{70}$ Hence, even if Alabama was able to evidence a large cost associated with educating undocumented students, such evidence would not be enough to justify the statute. The Plyler Court would not have been persuaded by that information alone. Alabama would have to show that the costs of denying an education are greater than the future costs associated with more unemployment, welfare, crime, loss of "the tax money [undocumented aliens provide] to states" and "contributions to the economy." There will never be a time when the benefits of education to society will be less than those of denying an education. In the Supreme Court's words, our public school system has "supreme importance" as the "primary vehicle for transmitting "the values on which our society rests.","72

By analogy, imagine that the administrators of New York City decided that it was not going to provide police service to the South Bronx. The City would state that it does not have enough funding to provide these services, and it is not in the interest of officer safety since this area is too dangerous. Under the logic of Section 28, if the

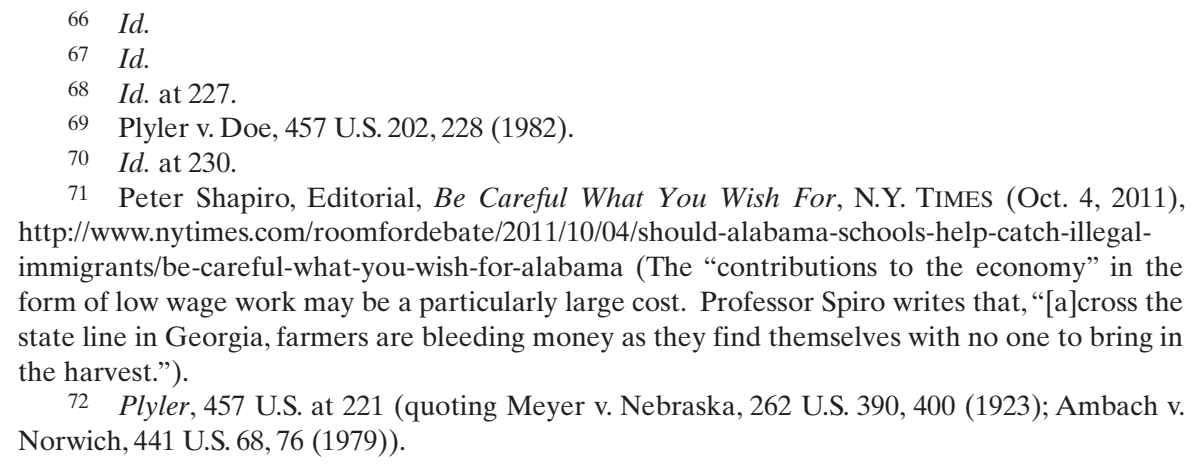
form of low wage work may be a particularly large cost. Professor Spiro writes that, "[a]cross the state line in Georgia, farmers are bleeding money as they find themselves with no one to bring in

72 Plyler, 457 U.S. at 221 (quoting Meyer v. Nebraska, 262 U.S. 390, 400 (1923); Ambach v. Norwich, 441 U.S. 68, 76 (1979)). the harvest."). 
City could gather information showing the benefits of not providing this service were great enough, the City would be justified in not doing so. Like education, however, it is hard to see how the cost savings in not providing police would be preferable to the costs associated with anarchy and loss of property and life that would most likely result. Providing basic law enforcement is preferred to non-enforcement, just like education is preferred to no education.

Furthermore, current understanding of the benefits associated with education is even greater today than when the Court decided Plyler. There is ample evidence showing the economic returns of an education; for example, the Census Bureau has found that college graduates earn almost double the amount that high school graduates earn. $^{73}$ Another study has shown that an additional high school graduate yields a public benefit of $\$ 209,000$ in more tax revenue and less government expenditure.

Even as a research study, Section 28 is not a good practice. If the statute was enacted for the purpose of studying the costs associated with undocumented immigration, it will not succeed in achieving its goal. It is known that persons will alter their behavior when they know they are being studied. ${ }^{75}$ Here, undocumented immigrants know their status is being scrutinized when the school officials ask for that information. Thus, undocumented students and their parents will alter their behavior accordingly. The information gathered by Section 28 will likely decrease enrollment either because undocumented families will know the state is keeping tabs on them and their children, or because they are afraid their immigration status will be revealed to federal authorities. Thus, any enrollment numbers will likely be smaller than the real numbers. Consequently, the costs would be undercounted. Early reports show that there is a decrease, not just in undocumented student enrollment, but Latino student enrollment overall in Alabama. ${ }^{76}$ This may be because there are mixed status families

73 Jennifer Cheeseman Day \& Eric C. Newburger, The Big Payoff: Educational Attainment and Synthetic Estimates of Work-Life Earnings, U.S. CENSUS BUREAU (July 2002), http://www.census.gov/prod/2002pubs/p23-210.pdf.

74 Clive Belfield, Henry Levin, Peter Muennig \& Cecilia Rouse, The Costs and Benefits of an Excellent Education for All of America's Children, CENTER FOR COST-BENEFIT STUD. OF EDUC. TCHRS. C., COLUM. UnIV. (Jan. http://www.cbcse.org/media/download_gallery/Leeds_Report_Final_Jan2007.pdf.

75 An example of this phenomenon is the Hawthorne Effect, in which research subjects alter their behavior when they know they are being observed. See Michel Anteby \& Rakesh Khurana, A New Vision, HARV. Bus. SCH., http://www.library.hbs.edu/hc/hawthorne/09.html (last visited Mar. 2, 2012).

76 Alan Gomez, Alabama Immigration Law Marked by Hispanic School Absences, USA TODAY (Oct. 2, 2011), http://www.usatoday.com/news/nation/story/2011-10-02/Alabamaimmigration-Hispanic-school-absences/50638454/1; see also Alabama: Many Immigrants Pull 
with both documented and undocumented members. Since persons can be prosecuted for encouraging undocumented immigrants to remain in Alabama, ${ }^{77}$ it is plausible that even a U.S. citizen or a lawfullypresent immigrant relative is afraid to enroll an undocumented child in school. It is even more likely that such persons do not know all of H.B. 56's provisions and are just afraid of it in general.

Certainly such a fear would be warranted since the legislature showed an animus toward undocumented people when it enacted the bill. $^{78}$ Alabama House Majority Leader, Micky Hammon, chief sponsor of H.B. 56, stated, "[w]hen this bill passes and is signed into law, I think you will see illegals leaving north Alabama and going elsewhere ... This bill is designed to make these people export themselves." ${ }^{79}$ He further exclaimed, "[w]e really want to prevent illegal immigrants from coming to Alabama and prevent those who are here from putting down roots." ${ }^{\text {s0 }}$

A better way to study the costs associated with undocumented students would be to take a small sample of certain representative schools throughout the state. Courts may prefer such a sampling approach since it is narrowly tailored and would have a less significant impact on undocumented people. Such an approach would also be cheaper for the state and school districts to implement since it would require less time and human resources.

\section{H.B. 56 Section 28 May Cause FERPA Violations}

The application of Section 28 may violate the Family Education and Privacy Rights Act (FERPA). ${ }^{81}$ This federal law prohibits the disclosure of certain identifying information about a student unless his or her parent gives written consent. ${ }^{82}$ Although the federal law contains certain exceptions, none of them apply with respect to Section 28 of

\footnotetext{
Children from Schools, N.Y. Times (Sept. 30, 2011), http://www.nytimes.com/2011/10/01/us/alabama-many-immigrants-pull-children-from-

schools.html?_r=1\&scp=1\&sq=Alabama \%20may \%20children $\% 20$ pull $\% 20$ children $\% 20$ from $\% 2$ 0school\&st=cse.

77 See supra notes 40-43 and accompanying text.

78 M.J. Ellington, House OKs Immigration Bill, THE TimES DAILY (Apr. 5, 2011), http:///www.timesdaily.com/article/20110406/NEWS.110409882?Title=House-OKs-immigrationbill.

79 Id.

80 R. Cort Kirkwood, Alabama Gov. Signs Immigration Bill; Leftists Outraged, THE NEw
} AM. (June 10, 2011), http://www.thenewamerican.com/usnews/immigration/7817-alabama-govsigns-immigration-bill-leftists-outraged.

8120 U.S.C. $\$ 1232$ (g) (2006).

82 Id. 
the Alabama law. ${ }^{83}$ A potential FERPA violation could occur if a school district turns over specific information on the undocumented student to the Alabama Department of Education for purposes of submitting the report to the legislature. A FERPA violation would also likely occur if the school decides it has to comply with Sections 5 and 6 of H.B. 56, which prohibit any "policy or practice" that "limits communication" with federal enforcement, and shares information about undocumented students or parents with federal authorities.

\section{LITIGATION OVER H.B. 56}

Once Governor Bentley signed H.B. 56 into law, the U.S. Department of Justice, a civil rights group, and a group of clergy filed suits in federal court with the result that only some sections of the law were preliminarily enjoined. ${ }^{85}$

\section{A. Section 8 of H.B. 56 Enjoined on Preemption Grounds}

In Hispanic Interest Coalition of Alabama v. Bentley, the United States District Court for the Northern District of Alabama enjoined Section 8 of H.B. 56, which prohibited aliens "not lawfully present" in the United States from enrolling in public post-secondary education. ${ }^{86}$ The second sentence of Section 8 defined aliens "not lawfully present in the United States" as those that do not "possess lawful permanent residence or an appropriate nonimmigrant visa under 8 U.S.C. $\S$ 1101." ${ }^{, 87}$ However, the Alabama legislature did not include refugees and asylum seekers, who, under U.S. immigration law, are lawfully present under other provisions of federal law, just not under 8 U.S.C. $\S$ 1101. ${ }^{88}$ Because only Congress may classify aliens, ${ }^{89}$ and since Alabama's classification of an alien contradicted federal law, Section 8 was preempted."

In Bentley, the plaintiff, Esayas Haile, sought a preliminary injunction claiming that he was a refugee and had standing to challenge

8334 C.F.R. $\$ 99.31$ (2012). For further information, see Questions and Answers for School Districts and Parents: Documentation, U.S. DEP'T EDUC., http://www2.ed.gov/about/offices/list/ocr/docs/qa-201101.pdf (last visited Mar. 10, 2012).

842011 Ala. LAWs 535 (H.B. 56 §\$ 5(a)-6(a)).

85 Campbell Robertson, Alabama Wins in Ruling on its Immigration Law, N.Y. TIMES (Sept. 30, 2011), http://www.nytimes.com/2011/09/29/us/alabama-immigration-lawupheld.html?ref=us.

86 Hispanic Interest Coal. of Ala. v. Bentley, No. 11-2484, 2011 WL 5516953, at *24 (N.D. Ala. Sept. 28, 2011).

87 Id. at $* 20$.

88 Id.

89 Plyler v. Doe, 457 U.S. 202, 225 (1982).

90 Hispanic Interest Coal. of Ala., 2011 WL 5516953, at *23. 
Section 8 because of his denial of an education. ${ }^{91}$ Interestingly, the federal government did not challenge Section 8 in its suit based on preemption. The Court suggested that if the Alabama legislature redrafts Section 8 so there is no contradiction with federal law, and it passes this new version, such a new Section 8 could stand under a preemption analysis since it seems this was a drafting error and not a purposeful attempt to exclude asylum seekers or refugees. ${ }^{92}$

\section{B. H.B. 56's Section 13 Enjoined on Preemption Grounds}

As previously discussed, ${ }^{93}$ Section 13(a)(1) makes it unlawful for a person to "conceal, harbor, or shield ... or conspire to conceal, harbor, or shield [an alien]. . from detection in any place in this state ...", and Section 13(a)(2) makes "induc[ing]" an alien to come to or reside in the state unlawful. ${ }^{95}$ Section 13(a)(3) criminalizes the "transport, or attempt to transport, or conspire to transport an alien" whose presence in the United States is in violation of federal law. ${ }^{96}$ Section 13(a)(4) prohibits entering into rental agreements with unlawful aliens."

The District Court granted a preliminary injunction invalidating Section 13 on preemption grounds." It noted that "Congress has provided a uniform, comprehensive scheme of sanctions for those who unlawfully enter the United States.", The district court used a "conflict preemption" analysis to invalidate the section. The federal government asserted that the state law "conflict[ed] with the operation of federal immigration law." Alabama claimed that it was "concurrent enforcement" with federal law. ${ }^{101}$ However, the court disagreed and concluded that Section 13 "actually prohibit[ed] conduct allowed under federal law and criminaliz[ed] conduct that is lawful under federal law." ${ }^{102}$ For example, federal law provides an exemption for clergy under its transportation and harboring scheme. ${ }^{103}$ Section 13 had no such exemption; instead, Section 13 only had exemptions for first respond-

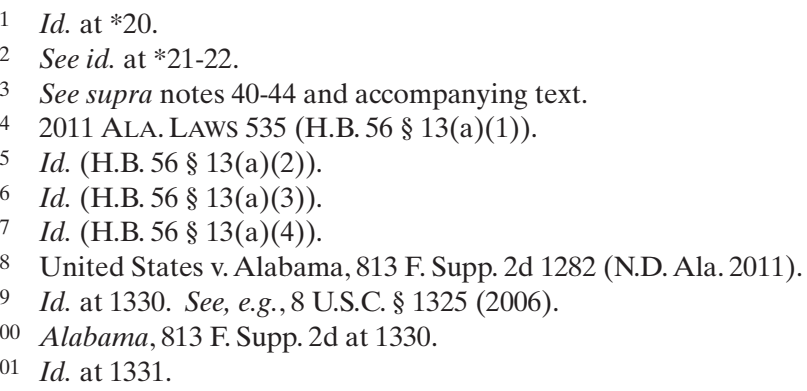


ers and protective service providers. ${ }^{104}$ Section 13(a)(2) was also unconstitutional because federal law did not make it a crime to "induce an illegal alien to enter Alabama from another state," only the inducing of an alien to enter the United States. ${ }^{105}$ The court also found conflicts between federal law and state law because Section 13(a)(3) and (4) had elements not present in the federal statute, such as punishing "transportation conspiracy" and "rental agreements." concern that Alabama courts would interpret "harboring" differently than federal courts and impose their own law. ${ }^{107}$ The court distinguished recent cases from other states in which federal courts did not find preemption when prosecuting employers for hiring undocumented aliens. ${ }^{108}$ According to the court, those cases concerned areas of license and regulation of employment where Congress has specifically preserved authority for the states. ${ }^{109}$

\section{Section 13 Could Also Have Been Found Unconstitutional Using a Plyler Analysis}

Section 13 would punish the "transportation" and "harboring" of aliens present in Alabama in violation of immigration law. ${ }^{110}$ It would also make it illegal to "encourage" such aliens to remain in Alabama." In the H.B. 56 litigation, civil rights plaintiffs raised the possibility that a violation of Plyler could result if schools could not transport undocumented children on buses. ${ }^{112}$ Also, if school officials protected an undocumented child in an emergency or when the parent was not available, a conflict with the anti-harboring provision would exist if that could be considered "harboring."

\section{Inconsistency Between the Eleventh Circuit and the Alabama District Court}

The District Court for the Northern District of Alabama did not enjoin Section $28 .^{113}$ The court failed to do so even though the federal

104 Id. at 1329.

105 See id. at 1334.

106 Id. at $1329,1324$.

107 Id. at 1335.

108 Id. at 1331 (distinguishing Chamber of Commerce v. Whiting, 131 S. Ct. 1968, 1979 (2011); Arizona Contractors Ass'n, Inc. v. Napolitano, Nos. CV07 1355 PHX NVW, CV07 1684 PHX NVW, 2007 WL 4570303, at*13-14 (D. Ariz. Dec. 21, 2007)).

109 Id.

110 See 2011 Ala. LaWs 535 (H.B. 56 § 13).

111 Id.

112 See Complaint for Declaratory and Injunctive Relief at II 232, Hispanic Interest Coal. of Ala. v. Bentley, No. 11-2484, 2011 WL 2654277 (N.D. Ala. July 8, 2011).

113 Alabama, 813 F. Supp. 2d at 1345 (N.D. Ala. 2011). 
government lawsuit asserted that Section 28 created a "mandatory data collection, classification, and reporting requirement", and was an "impermissibl[e] ...registration scheme for children (and derivatively their parents)" akin to the one the Supreme Court invalidated in Hines v. Davidowitz. ${ }^{114}$ In Hines, the Supreme Court held that a state "cannot inconsistently with the purposes of Congress, conflict or interfere with, curtail or complement, the federal law, or enforce additional or auxiliary regulations." 115 The Pennsylvania statute required that all aliens over eighteen register annually and carry an alien registration card. $^{116}$ The state law was unconstitutional because its independent, state-specific registration scheme conflicted with a federal Alien Registration Act, and was an "obstacle to the accomplishment and execution of the full purposes and objectives of Congress."

In failing to enjoin Section 28 of H.B.56, the district court distinguished Section 28 from the Pennsylvania statute because it did not "attempt to register anyone, or create registration requirements in addition to those established by Congress in the INA."118 The court did not elaborate on how exactly H.B. 56 was different. Yet two weeks later, in an unpublished opinion, the Eleventh Circuit Court of Appeals enjoined Section $28 .^{119}$ The appeals court did not elaborate on its rationale.

Even though the Eleventh Circuit enjoined Alabama's enforcement of Section 28 on interlocutory appeal by the federal government, ${ }^{120}$ it remains a threat to the education of undocumented children. Its "chilling effect" has already resulted in many Latino children's absences.

114 Id. at 1348 (citing Hines v. Davidowitz, 312 U.S. 52 (1941)).

115 Hines v. Davidowitz, 312 U.S. 52, 66-67 (1941).

116 Id. at 59-60.

117 Id. at 67

118 Alabama, 813 F. Supp. 2d at 1348.

119 United States v. Alabama, Nos. 11-14532, 11-14535, 2011 WL 4863957 (11th Cir. Oct. 14, 2011).

120 Id. The Eleventh Circuit did not elaborate on the merits of the federal government's claim concerning Section 28 except to state that the stringent requirements for granting the injunction pending appeal had been met. Id. Interestingly, however, in addressing the first factor for granting the injunction, the Circuit Court stated that "[a] substantial likelihood of success on the merits requires a showing of only likely or probable, rather than certain, success." Id. (quoting Schiavo ex rel. Schindler v. Schiavo, 403 F.3d 1223, 1232 (11th Cir. 2005)). Furthermore, the court noted that restraint must be shown in enjoining legislative enactments before there is a full trial on the merits unless demanded by the Constitution. Id. Although Alabama is enjoined from enforcing Section 28 now, it is unclear what the future of the Act will be after a trial on the merits. 


\section{RECENT ANTI-IMMIGRANT LEGISLATION IN OTHER STATES AND ITS IMPACT ON THE EDUCATION OF UNDOCUMENTED STUDENTS}

While Alabama's H.B. 56 is certainly the most comprehensive and far-reaching measure, states such as Georgia, South Carolina, Utah, and Indiana have enacted statutes that impact the education of undocumented children. In each of these states, the U.S. Department of Justice, along with various civil rights, religious, community, and business groups have already raised challenges to the laws on the basis of federal preemption, as well as constitutional protections under the Fourth and Fourteenth Amendments.

\section{A. Utah}

Utah H.B. 497, signed into law in March of 2011, includes the requirement for the determination of immigration status by state and local law enforcement. ${ }^{121}$ The Act also amends Section 76-9-2901, concerning the transporting or harboring of illegal aliens, to make it unlawful to "encourage or induce an alien to come to, enter, or reside in [the] state ...." Utah's law does not require the same strict immigration status information gathering as Alabama's H.B. 56, nor does it include a broad provision concerning the transportation or harboring of undocumented aliens. Importantly, unlike Alabama's H.B. 56, Utah's amendment to the harboring laws would likely not criminalize a parent's transportation of an undocumented child within the state since Section 76-10-2901(2)(a) requires that the transportation be done "for commercial advantage or private financial gain.","23

On May 3, 2011, the National Immigration Law Center, ACLU, and ACLU of Utah filed a class action seeking declaratory and injunctive relief on the grounds that federal law preempts and that H.B. 497 violates the constitutional protections of inter alia, the Equal Protection Clause of the Fourteenth Amendment. ${ }^{124}$ The court granted a Temporary Restraining Order in favor of Plaintiffs and stayed the execution of H.B. $497^{125}$ until hearing of Plaintiffs' Motion for Preliminary Injunction on February 17, 2012. ${ }^{126}$

121 See Illegal Immigration Enforcement Act, ch. 21, 2011 UTAH LAWs 21 (codified as amended at 2011 UTAH CODE ANN. §§ 76-9-1001 to -1009).

122 Id. § 76-10-2901(2)(c).

123 Id.

124 Complaint for Declaratory and Injunctive Relief at II 10, Utah Coal. of La Raza v. Herbert, No. 11-401 (D. Utah May 3, 2011).

125 Order, Utah Coal. of La Raza v. Herbert, No. 11-401, Doc. No. 45 (D. Utah May 11, 2011).

126 Order to Consolidate Cases and to Set Briefing Schedule, Utah Coal. of La Raza v. Herbert, No. 11-401, Doc. No. 129 (D. Utah Nov. 28, 2011). 


\section{B. Georgia}

Georgia's H.B $87^{127}$ includes provisions that make it a state crime to harbor or transport undocumented persons within the state. ${ }^{128}$ The Act states that "[a] person who, while committing another criminal offense, knowingly and intentionally transports or moves an illegal alien in a motor vehicle ... shall be guilty of the offense of transporting ... an illegal alien." ${ }^{, 129}$ This places undocumented parents in a very dubious position. Since traffic violations are considered "criminal offenses" under the statute, it is foreseeable that criminal penalties could be applied to parents who are transporting undocumented children to school. Certainly, the thought of such extreme consequences as a result of taking undocumented children to school will be a factor in deciding whether to send them at all.

On June 8, 2011, Plaintiffs' nonprofit organizations, business associations, and certain individuals filed a Motion for Preliminary Injunction to enjoin portions of H.B. 87 that were to be effective on July 1, 2011. ${ }^{130}$ Plaintiffs' nonprofit organizations challenged the Act on the grounds of preemption, and on other constitutional grounds. ${ }^{131}$ Accordingly, the District Court enjoined the enforcement of Sections 7 and 8 of H.B. 87 on the basis of federal preemption and held that the Act did not violate the other liberties and rights asserted by Plaintiffs. $^{132}$ The state has appealed the decision to the Eleventh Circuit Court of Appeals. ${ }^{133}$

\section{Indiana}

In May of 2011, the Indiana House and Senate passed S.B. 590 and H.B. 1402. S.B. 590 requires state and local law enforcement officers to enforce federal immigration laws and verify the immigration status of individuals that they lawfully stop, detain, or arrest. ${ }^{134}$ Addi87).

127 Illegal Immigration Reform and Enforcement Act of 2011, 2011 GA. LAWs 252 (H.B.

128 Id. (H.B. $87 \S 7$, Art. 5 (codified as amended at 2011 GA. CODE ANN. §§ 16-11-200(b) and $201(\mathrm{~b}))$.

129 Id. § 16-11-200(b) (2011).

130 Ga. Latino Alliance for Human Rights v. Deal, 793 F. Supp. 2d 1317, 1322-23 (N.D. Ga. 2011).

131 Id. at 1323,1328 .

132 Id. at 1340.

133 Brief for Judicial Watch, Inc. as Amici Curiae Supporting Defendant-Appellant, Ga. Latino Alliance for Human Rights v. Deal, 793 F. Supp. 2d 1317 (N.D. Ga. 2011) (No. 11-13044).

134 Act of May 10, 2011, 2011 IND. SEA 590, § 3 (codified as amended at IND. CoDE $§ 5-2-$ 19-5(a) (2011)). Individual alien plaintiffs filed suit to challenge the constitutionality of S.E.A. 590 and sought to enjoin Sections 18 (creating violation under Indiana law for any person to knowingly offer or accept a consular identification card as valid form of id) and 19 (authorizing 
tionally, H.B. 1402, and S.B. 590 Sections 12, 13, and 14 exclude undocumented students from receiving in-state tuition rates at public universities and excludes them from receiving financial or scholarship aid. $^{135}$

Although the primary education of undocumented students is not being facially restricted or inhibited, the state of Indiana is clearly limiting the educational advancement of these individuals. The consequences of this are the same as those that concerned Justice Brennan in Plyler: the "depriv[ation] . . . of any disfavored group of an education ... foreclose[s] the means by which that group might rise to the level of esteem in which it is held by the majority." ${ }^{136}$ Importantly, it must be recognized that Plyler was decided nearly three decades ago, a time when much more could be accomplished professionally with a high school diploma. In today's technology-dependent world, access to higher education is more important than ever before. Indiana's denial of access to undocumented students only serves as a mechanism to further disenfranchise an educationally disadvantaged group.

\section{South Carolina}

Similar to Georgia's H.B. 87, ${ }^{137}$ South Carolina's S.B. 20 provides strict penalties for knowingly transporting or harboring a person unlawfully in the country, making it a felony. ${ }^{138}$ Thus, parents, friends, and other persons run the risk of a felony arrest by driving an undocumented student to school or having him or her in their home. ${ }^{139}$ Although the law does not require that schools review and compile statistics on the immigration status of their students, the increased risks that arise as a result of the new measure will likely have a negative effect on the undocumented student population. It will become increasingly difficult for undocumented aliens to remain in South

law enforcement to make warrantless arrests based on immigration status) of the Act. Id. The District Court granted plaintiffs preliminary injunction as to Sections 18 and 19 on the grounds of preemption, the Fourth Amendment, Equal Protection, and Due Process. Buquer v. City of Indianapolis, 799 F. Supp. 2d 905 (S.D. Ind. 2011).

135 Act of July 1, 2011, ch. 11, 2011 Ind. S.B. $590 \S \S 12-14$ (codified as amended at IND. CODE $\S \S 21-11-7.5-1,-14-11-1$, and -15-2-5 respectively (2011)).

136 Plyler v. Doe, 457 U.S. 202, 222 (1982).

137 See supra notes 126-128 and accompanying text.

138 Act of June 27, 2011, 2011 S.C. S.B. $20 \S 4$, (codified as amended at S.C. CoDE $§ 16-9-460$ (2011)) (under Georgia's H.B. 87, a similar offense is only a misdemeanor).

139 Parents of Students Worry over South Carolina Immigration Law, Fox NEWs (Nov. 16, 2011), http://latino.foxnews.com/latino/news/2011/11/15/s-carolina-immigration-law-worrieslatino-students/. 
Carolina with this new mandate from the Legislature emphasizing immigration enforcement. ${ }^{14}$

As with the other state legislation discussed above, S.B. 20 has also been challenged by a number of individuals, civil rights and nonprofit groups ${ }^{141}$ as well as the U.S. Department of Justice. ${ }^{142}$ On December 22, 2011, the District Court for the District of South Carolina issued an order granting private plaintiffs' and the Federal Government's motions for preliminary injunction as to Sections 4,5 , and 6 of the Act. ${ }^{143}$ The injunction was granted on the basis of preemption. ${ }^{144}$ Accordingly, those sections of S.B. 20, that make transporting and harboring undocumented aliens state felonies are enjoined pending a full trial on the merits.

\section{CONCLUding ThOUGHTS}

Plyer provides that state laws that interfere with the guarantee of a free public education are ineffective tools for immigration reform. ${ }^{14}$ The use of undocumented schoolchildren as pawns in the raging immigration debate is inappropriate and inconsistent with Plyler. The protection Plyler affords has endured thirty years, in large part because it is a high water mark in United States jurisprudence that recognizes this country's status as a nation of immigrants. The Supreme Court in Plyler recognized the innocence of undocumented children and that they should not be penalized for the acts of their parents, which cannot be changed by an innocent child seeking an education. ${ }^{146}$ Creating a climate of fear that would induce the parents of more than a thousand Latino students in Alabama to be absent from school ${ }^{147}$ is not in the best interest of the children, the state, or the nation. Even

140 Act of June 27, 2011, 2011 S.C. S.B. 20 \$ 17 (codified as amended at S.C. CODE $§ 23-6-60$ (2011)), creates the Illegal Immigration Enforcement Unit within the Department of Public Safety. The task of the Unit is to enforce federal and state immigration laws throughout the state. $I d$. The Unit will be separate and distinct from all other state law enforcement agencies and will have jurisdiction in all counties. Id. at $\S \S 23-6-60(\mathrm{C})(2)(\mathrm{c})-(\mathrm{d})$.

141 Complaint for Declaratory and Injunctive Relief, Lowcountry Immigration Coal. v. Haley, No. 11-2779, 2011 WL 4824401 (D.S.C. Oct. 12, 2011).

142 Josh Gerstein, South Carolina Immigration Law Sparks Suit From Justice Department, POLITICO (Oct.

31 ,

2011), http://www.politico.com/news/stories/1011/67274.html\#ixzz1cOV6vFh8.

143 United States v. South Carolina, No. 11-2958, 2011 WL 6973241 (D. S.C. Dec. 22, 2011).

144 Id.

145 See Plyler v. Doe, 457 U.S. 202 (1982)

146 Id. at 220 (quoting Trimble v. Gordon, 430 U.S. 762, 770 (1977)).

147 Verna Gates, Appeals Court Blocks Parts of Alabama Immigration Law, REUTERs (Oct. 14 , 2011), http://www.reuters.com/article/2011/10/14/us-usa-immigration-alabamaidUSTRE79D4SQ20111014 (reporting that 1054 Hispanic students were absent from Alabama schools the day H.B. 56 was scheduled to take effect). 
those who support H.B. 56 are concerned about targeting children, as evidenced by the words of this Alabama resident, "I think a lot of what we're hearing is panic, and if (immigrants are) here illegally they should be scared, but I don't see any reason to drag children into something that's not even sorted out yet."148 